\title{
TWO DIFFERENT PERSPECTIVES OF MACINTYRE ON HUME: REVISITING ALASDAIR MACINTYRE'S APPROACH TO DAVID HUME'S MORAL PHILOSOPHY
}

\author{
Elif Nur ERKAN BALCI*
}

\begin{abstract}
Öz
Alasdair MacIntyre, modern ahlakı duygucu karaktere sahip olmakla eleştirir ve merkez eseri Erdem Peşinde'de bu ahlaka içerik kazandıran temel şahsiyet olarak David Hume'a işaret eder. MacIntyre'a göre Hume'un ve sonrasında onun etkisiyle gelişen duygucu ahlak felsefesi, genelde klasik ahlak geleneğine, özelde ise Aristoteles ahlak felsefesine temel zıtlıklar içerir. Ancak MacIntyre, bir taraftan bu zıtlığın Erdem Peşinde kitabında altını çizerken, diğer yandan Erdem Peşinde dışındaki -özellikle sonraki- yazılarında Hume ve Aristoteles'i ahlakın nasıl anlaşılması gerektiği noktasında benzer bakış açılarına sahip olarak bir araya getirir. Bu durum, MacIntyre'ın Hume yorumunu, görünüşte birbirini dışlayan bu anlama şekillerine işaret eden, iki farklı bakışla ele alınması gerekliliğini ortaya çıkarır. Bu makale, bu iki bakma şeklini bir araya getirerek, MacIntyre'ın Hume'u modern duyguculuk içerisinde konumlandırmasına dair bütünlüklü bir kavrayışı ortaya çıkarmayı amaçlamaktadır.
\end{abstract}

Anahtar Kelimeler: David Hume, Alasdair MacIntyre, Duyguculuk, Aristoteles, Modern ahlak, Pratik akıl.

\begin{abstract}
Alasdair MacIntyre criticizes the modern morality for having emotivist features and in his central book After Virtue he points out that David Hume is the main personality who provides these emotivist contents to the modern morality. According to MacIntyre, Hume's and the modern emotivist moral philosophy include fundamental contrasts generally with the classical moral tradition particularly with Aristotle's moral philosophy. However, MacIntyre underlines these contrasts in After Virtue, he in his other texts out of After Virtue, distinguishably brings Hume and Aristotle together as they both have similar standpoints about how to understand morality. Therefore, MacIntyre's interpretation on Hume needs to be examined with a perspective pointing these two different and seemingly mutually exclusive aspects. Putting together these two perspectives, this article aims to construct a holistic comprehension about MacIntyre's placing Hume in the modern emotivism.
\end{abstract}

Key Words: David Hume, Alasdair MacIntyre, Emotivism, Aristotle, Modern morality, Practical rationality.

\section{Introduction}

In After Virtue, one of the most controversial books within moral philosophy in last decades, Alasdair MacIntyre tackles actors and problems of modern morality with a very complex and robust rhetoric. MacIntyre, throughout

* Phd Research Assistant at Sakarya University, Departmant of Philosophy of Religious Sciences, (balci@sakarya.edu.tr).

I would like to express my gratitude to the Abroad Research Scholarship Programme of TUBITAK (The Scientific and Technological Research Council of Turkey) for supporting me during the writing of this article. 
this book, makes David Hume one of the main targets of his critiques towards modern morality, because he sees Hume as the the leading character of modern moral theories later advanced particularly by Kant and Kierkegaard. ${ }^{1}$ MacIntyre focuses predominantly on Hume's well-known distinction between reason and moral judgments, and his understanding of human nature. Having discussed his approach to these two points, MacIntyre presents Hume's practical reasoning (and also, with Hume's influence, Kant's practical reasoning) as a central challenge to Aristotelian practical reasoning. ${ }^{2}$

In this paper, I will argue for that MacIntyre's presentation of Hume's morality as anti-Aristotelian could be misleading and incomplete for readers of After Virtue, who do not read MacIntyre's other complementary texts about Hume. In these texts MacIntyre understands Hume partly as the one of last followers of Aristotelian thinking on morality in modernity, which seems not very visible in After Virtue. Assuming these two different approaches to Hume are complementary, this article attempts to develop a holistic reading of MacIntyre's different interpretations of Hume's moral philosophy. Since only this holistic reading can provide a better understanding of MacIntyre's engagement with Hume.

This preliminary observation prompts two questions: Firstly, which features of Hume's moral philosophy are represented as anti-Aristotelian? And secondly, which features of Hume's moral philosophy are represented as Aristotelian in MacIntyre's texts? The first part of this article is related to the first question and will be focusing only on After Virtue. The second part will be answering the second question through MacIntyre's other texts, apart from After Virtue. Besides having answered these two questions, this article will not address Hume's moral philosophy as a single and comprehensive subject matter.

\section{The First Perspective: MacIntyre's Understanding of Hume's Morality as anti-Aristotelian in After Virtue}

MacIntyre's understanding of Hume in After Virtue is based on his general perception about the emotivist character of modern morality. For MacIntyre, modern morality is essentially theorized through emotivist grounds, which differ radically from the Aristotelian moral conceptions and vocabularies. In

1 Alasdair MacIntyre, After Virtue: A Study in Moral Theory, New York: Bloomsbury, 3rd. Edition, 2011, p. 55.

2 MacIntyre, After Virtue, p. 315. 
After Virtue, MacIntyre defines emotivism in the frame of a theory of the meaning in the following statements:

Emotivism is the doctrine that all evaluative judgments and more specifically moral judgments are nothing but expressions of preference, expressions of attitude or feeling, insofar as they are moral or evaluative in character. ${ }^{3}$ [Therefore] Emotivism thus rests upon a claim that every attempt, whether past or present, to provide a rational justification for an objective morality has in fact failed. ${ }^{4}$

As MacIntyre strongly believes the important impact of emotivism on the philosophical and social contexts, he recognizes Hume as the main character of emotivism. For him, Hume very early contributed to the emergence of the theory of emotivism in the $20^{\text {th }}$ century through his sophisticated and complex infrastructure within his moral philosophy. ${ }^{5}$ As MacIntyre observes, the contribution of Hume to emotivism can be seen in his effort to disconnect morality from the sphere of reasoning. That is to say, he transforms moral issues into psychological issues. According to MacIntyre, this understanding of morality rests upon Hume's very first assumption that "either morality is the work of reason or it is the work of the passions..." 6 Based on this assumption, Hume reaches to his so-called ultimate verdict that morality cannot be issued by reason. ${ }^{7}$ He formulates this as following:

Morality... is more properly felt than judged of; though this feeling or sentiment is commonly so soft and gentle, that we are apt to confound it with an idea, according to our common custom of taking all things for the same, which have any near resemblance to each other. ${ }^{8}$

This prominent passage, a nutshell of emotivist modern morality, provides MacIntyre a fertile ground to criticize Hume. Put differently,

3 MacIntyre, After Virtue, p. 13.

4 MacIntyre, After Virtue, p. 22. Here it is important to indicate that however, MacIntyre defines emotivism as a philosophical theory, he uses emotivism in a wider domain, as not just a theory in philosophy but also as a social concept. For him, in our time, emotivism "is a theory embodied in characters who all share the emotivist view of the distinction between rational and non-rational discourse, but who represent the embodiment of that distinction in very different social contexts." (See MacIntyre, After Virtue, p. 35.) Therefore, what he understands from emotivism is the "emotivist culture" (for this usage see also see ibid., Part II and Part III) is in our age, so that this culture even hosts the claims of philosophers, for example within analytical philosophy, who do not consider themselves as emotivist. (See MacIntyre, After Virtue, p. 22-25.) Hence, for MacIntyre, the power of emotivism in philosophical and social domains is more than it actually is comprehended.

5 MacIntyre, After Virtue, p. 16, 57, and 20. MacIntyre also explicitly indicates that Hume influenced Stevenson very much. See Alasdair MacIntyre, The Tasks of Philosophy, vol: 1, Cambridge: Cambridge University Press, 2006, p. 110.

6 MacIntyre, After Virtue, p. 58.

7 MacIntyre, After Virtue, p. 58.

8 David Hume, Treatise of Human Nature 470. 
MacIntyre's problem with Hume's moral understanding in After Virtue cannot be detached from his general critiques of modern emotivist moral assertions. Therefore, why and how MacIntyre criticizes Hume's moral philosophy as anti-Aristotelian, will be more lucid when I first elaborate MacIntyre's critiques of emotivist character of modern morality. Moreover, this understanding will also bring us to the antagonism between Hume's way of explaining morality and Aristotle's way. ${ }^{9}$

Hume's morality and emotivist morality have a common ground, as MacIntyre identifies, especially when it comes to the perception of morality as the subject of feelings and personal preferences, and problematic outcomes of this perception in practical issues. ${ }^{10}$ The first problematic outcome of the emotivist explanation of morality is the problem of the justification of moral action. As succinctly stated in After Virtue, the emotivist moral agent will not be able to answer the questions justifiably, such as "what sort of person am I to become?", "which ought I to choose?" or "how ought I to choose?"11 In emotivist modern framework, the incapability of the moral agents to answer these questions is the fundamental starting point for MacIntyre's critique of modern emotivist morality and therefore of Hume's morality. Because these questions are not able to be answered justifiably, MacIntyre stigmatizes the modern emotivist conceptions as totally corrupt and failed moral projects. ${ }^{12}$

With respect to the justification problem of morality, the second problematic outcome of the emotivist explanation of morality as personal preferences and feelings clearly manifests itself at the structural level of the moral arguments and of moral agent. According to MacIntyre, in the argument level, one can easily notice first; "the conceptual incommensurability of the rival arguments" and second; "assertive use of ultimate principles in attempts to close moral debate". ${ }^{13}$ That means, since each modern emotivist rival arguments uses very different normative and evaluative versions from each other, one cannot rationally claim the validity of any particular argument against others. Thus, the clash of moral arguments appears to us as infinite and unresolvable. Concerning this, in the structure of moral agent, the result of failure in justifying morality is the following: the agent does not have a rational chain of moral hierarchy and of teleology in his life anymore, so that the moral philosophers treat the agent

9 MacIntyre, After Virtue, p. 22.

10 MacIntyre, After Virtue, p. 22.

11 MacIntyre, After Virtue, p. 138.

12 MacIntyre, After Virtue, p. 23.

13 MacIntyre, After Virtue, p. 41. 
as a sole authority in her moral life. ${ }^{14}$ Therefore, MacIntyre identifies this agent as a modern and emotivist self, since the self has not a justified and ultimate criterion of her action, and thus, she has to place her moral commitments in a non-rational frame. ${ }^{15}$

At this point, I need to relate Hume's own approach to morality with these two significant features of emotivist modern morality. In After Virtue, MacIntyre makes some remarks that Hume anticipates the both problems of modern emotivist morality in A Treatise of Human Nature (thereafter Treatise), and tries to overcome them in An Enquiry Concerning Human Understanding (thereafter Enquiry). As noted in the beginning, Hume acknowledges moral judgments as expressions of personal feelings that supply a necessary base for the moral emotivism. But additionally, he also accepts general rules while making these moral judgments. As MacIntyre points out, Hume strongly believes in the Treatise that there are indeed such rules and he explains them as useful and motivational mediums co-working with personal desires and passions. In other words, a person who will make a moral judgment will act according to two elements: her desires and general rules. Hume convinces himself in the Treatise that the general rules do not contradict with the personal desires. Hence, for MacIntyre, on the one hand, Hume assumedly seems to solve the problem of incommensurability of emotivist moral arguments by accepting the general rules, but on the other hand, he does not explain how one's personal desires can always be compatible with such rules. Certainly there will be plenty of general rules to which we are not apt to obey, because they will probably be opposing to our desires. ${ }^{16}$

When it comes to the idea of presenting personal desires as always agreeable with general rules, MacIntyre focuses in After Virtue on the outcome of this idea regarding understanding of virtue and vice. That Hume grounds the moral judgments on feelings leads him also to comprehend vice and virtue as they both are based on the same footing. Hume says on this point, "...the distinction of vice and virtue is not founded merely on the relations of objects, nor is perceived by reason." 17 He also says, "To have the sense of virtue, is nothing but to feel a satisfaction of a particular kind from the contemplation of a character. The very feeling constitutes our praise or admiration." 18 If virtue is based on the feeling of approval, the virtuous

14 MacIntyre, After Virtue, p. 9, 75.

15 MacIntyre, After Virtue, p. 36, 38.

16 MacIntyre, After Virtue, p. 57, 58.

17 Hume, Treatise 469.

18 Hume, Treatise 471. 
behavior and action will always correspond with personal desires and likewise obeying the precepts of virtue will always be agreeable by the agent. This is the point where the importance of MacIntyre's question lays: what about the virtues such as the virtue of justice, which would not always be demanded by the agent itself in the case of self-interest? ${ }^{19}$

As MacIntyre notices, Hume cleverly avoids this question by dividing the moral judgments into two virtues: natural and artificial. For Hume, the natural virtues are the virtues which are always useful and agreeable for a person. As for the artificial virtues, they are the virtues which are inhibitive to human desires because some of them can be destructive for the society. For example, while every person perceives the virtue of generosity in others always as useful and agreeable, they however do not have the same standpoint for the virtue of justice. This is so, since the virtue of justice will not be always pleasant in terms of self- interest, even though we teach each other to respect the principles of justice and to find those principles agreeable. MacIntyre reformulates his objection against Hume as following: "why do we find the justice useful if there is no satisfaction for our selfinterest?" 20

MacIntyre believes that Hume is self-confident that we will find the justice useful and therefore he invokes, partly in the Treatise but more strongly in the Enquiry, the concept of "the communicated passion of sympathy." ${ }^{21}$ According to Hume, thanks to "the communicated passion of sympathy" we find the principle of justice agreeable. This is so, because we sympathize with others by nature. ${ }^{22}$ As underlined by MacIntyre, we can still see two confusing issues here: Firstly, how Hume can assume that "the communicated passion of sympathy" is a natural and simple passion for everyone? There can be always an example where this passion will not work

19 MacIntyre, After Virtue, p. 267.

20 MacIntyre, After Virtue, p. 267.

21 Hume, Treatise 370. And see MacIntyre, After Virtue, p. 267. MacIntyre quotes here two different statements of Hume. In the Treatise, while Hume discusses the idea of love of others as a prerequisite for the foundation of justice, He says: "In general, it may be affirmed, that there is no such passion in human minds, as the love of mankind, merely as such, independent of personal qualities, of services, or of relation to ourself." See, Hume, Treatise 481. And he says in the Enquiry, Section V, Part II: "It appears also, that in our general approbation of characters and manners, the useful tendency of the social interests moves us not by any regards to self-interest, but has an influence much more universal and extensive. It appears that a tendency to public good, and to the promoting of peace, harmony, and order in society does always, by affecting the benevolent principles of our frame, engage us on the side of the social virtues." See Alasdair MacIntyre (Ed.), Hume's Ethical Writings: Selections from David Hume, Notre Dame: University of Notre Dame Press, 1965, p. 76.

22 Hume, Treatise, 481. 
for every person. Secondly, Hume contradicts himself, because while he already excludes any kind of external criterion in making a judgment concerning the virtue and vice, but at the same time, he accepts social criteria for feelings of approval and disapproval. As in the case of the artificial virtues, Hume apparently has to recognize an external social mechanism for the virtue of justice. ${ }^{23}$

MacIntyre underlines that Hume, with the idea of sympathy wants to invent a supplementary element in the gap between the set of reasons that support an absolute and unconditional adherence to the rules and the set of reasons that spring from our desires and interests. But MacIntyre sees it as an artificial and vain attempt and calls it as a "philosophical fiction", since this gap is so wide that it could not be filled with the concept of sympathy. ${ }^{24}$ The same attempt, for MacIntyre, can also be seen in Hume's incompatible arguments, which are also results of his fundamental assumption about the reduction of morality into the feelings. These arguments bear a more fundamental weakness as in the presentation of the knowledge of being virtuous and vicious. According to MacIntyre, this weakness lays in the fact that as if this knowledge is obvious and simple matter for everyone. ${ }^{25}$ As he says in the Enquiry Section I:

The final sentence' it is probable, which pronounces character and actions, amiable or odious, praiseworthy or blamable; that which stamps on them the mark of honor or infamy, approbation or censure; that which renders morality as active principle and constitutes virtue or happiness and vice or misery-it is possible, I say, that the final sentence depends on some internal sense or feeling which nature has made universal in the whole species. ${ }^{26}$

In the same fashion but more strongly he says in the same place:

The quick sensibility which, on this head, is so universal among mankind, gives a philosopher sufficient assurance that he can never be mistaken in forming the catalogue or incur any danger of misplacing the object of his contemplation: he needs only enter into his own heart for a moment and consider whether or not he should desire to have this or that quality ascribed to him... ${ }^{27}$

MacIntyre questions again the self-confidence of Hume about the universality of human nature which here refers to an unmistakable acknowledgment about virtues. MacIntyre discusses the presentation of the agent in the passages as "we" pronoun. Who are the people whom Hume

23 MacIntyre, After Virtue, p. 267ff.

24 MacIntyre, After Virtue, p. 57f.

25 MacIntyre, After Virtue, p. 267f.

26 MacIntyre (Ed.), Hume's Ethical Writings, p. 26.

27 MacIntyre (Ed.), Hume's Ethical Writings, p. 27. 
addresses as "we"? MacIntyre underlines here again Hume's presumption about the idea of human nature which is the same and constant for all humankind in all different conditions. And actually, according to him, this is a "stubborn realism" of Hume, which prevents him to realize how his theory is very inconsistent with the human nature in reality and his own statements about the virtue of justice. He thinks that this is the point where Hume feels compelled to apply the external social mechanism as the idea of sympathy. ${ }^{28}$

How can all these features of Hume's morality be characterized as antiAristotelian? Thus far, I have tried to indicate the emotivist features of Hume's morality and its problematic outcomes in the perspective of MacIntyre. Now it is necessary to understand, why Hume's moral position is very much opposed with Aristotle's. Hume's conception of the human nature provides a very useful starting point to see the difference between these two moral perspectives, since his misconception of human nature constitutes the main opposition with the Aristotelian conception of human nature $^{29}$ and morality as a whole. We can follow this opposition in three appearances:

For MacIntyre, the first and foremost appearance of this misconception can be seen in the rejection of the teleological aspect of human nature in Aristotle. ${ }^{30}$ To indicate the opposition between the conceptions of Aristotle's and Hume's human nature (and including modern emotivist human nature) is possible with a threefold schema, which based on the concept of man in Aristotle in Nicomachean Ethics (NE), as illustrated in After Virtue. At the first stage of this schema, a person has an "untutored human nature" and at the second stage the person is a "man-as-he-could-be-if-he-realized-his-telos" 31 ; and finally at the third stage the person has "the moral precepts which enable him to pass from one state to the other." 32 For MacIntyre, this Aristotelian threefold schema legitimates the task of morality, so that a person justifiably can move forward from the first stage to the second. Making this transition justifiably possible requires the notion of human telos

28 MacIntyre, After Virtue, p. 267f. Here MacIntyre also recognizes this conception of human nature as a shared understanding of seventeenth and eighteenth centuries. Although the moral philosophers of these centuries presuppose different characteristics of human nature, they all shared the idea of "single and unitary human nature." See MacIntyre, "Moral Philosophy: What Next?", Revisions: Changing Perspectives in Moral Philosophy, Notre Dame: University of Notre Dame Press, 1983, pp. 1-15., p. 7.

29 See Aristotle, Nicomachean Ethics (thereafter NE) 1097b: "...human being is by nature a social being."

30 MacIntyre, After Virtue, p. 65, 269.

31 See NE $1177 \mathrm{~b} 30$ and the beginnig of 1178a.

32 MacIntyre, After Virtue, p. 65. And see also Aristotle, NE 1179b. 
which has to be fundamentally presupposed in the notion of human nature. ${ }^{33}$

Whereas in Hume's morality as MacIntyre underlines, a person is thought just as "man-as-he-happens-to-be." And therefore unlike Aristotle, modern perception of human being is that the person situates on an "untutored state". This perception denies any teleological background of human. Therefore there is no transition in the moral position of human being. On the contrary, Aristotle's precepts of enjoying virtues and of prohibiting vices are always situated according to this transition and they aim to educate us about how we can realize our telos, our true end. ${ }^{34}$ Moreover, our desires and emotions do not disappear in this transition; on the contrary, they are elements that need to be educated by the use of these precepts and by the cultivation of those habits of action. Reason in this process informs us regarding what our telos is, and how we can reach to it. This is the study which Aristotelian ethics prescribes. ${ }^{35}$

Herewith we can complete the Aristotelian threefold human nature. In order to have an intelligible and justified conception of ethics and human nature, these three elements must be properly presupposed in human nature. The distinctive, non-transitional understanding of human nature is, for MacIntyre, a notorious sign of modern emotivist moral theories, as well as of Hume's morality. According to MacIntyre, this deficient task will always remain a "quixotic" and "self-appointed" task for modernity, since morality, disengaged from its original frame, will always be either a radically transformed morality or not morality itself at all. ${ }^{36}$

As MacIntyre points out, the second appearance of the anti- Aristotelian misconception of human nature in emotivist ground embodies itself in a well-known discussion about "is and ought problem" among modern moral philosophers. The motto of this discussion is that "no valid argument can move from entirely factual premises to any moral or evaluative conclusion..." 37 To put it differently, this statement denies any relationship between the precepts of morality and the fact of human nature. At this point, MacIntyre indicates Hume's famous influence on this discussion in the Treatise where Hume says the following:

In every system of morality, which I have hitherto met with,... that the author proceeds for some time in the ordinary way of reasoning, and establishes the

33 MacIntyre, After Virtue, p. 63f.

34 See for example Aristotle, NE 1144b and 1105b.

35 MacIntyre, After Virtue, pp. 63-67.

36 MacIntyre, After Virtue, pp. 63-67.

37 MacIntyre, After Virtue, p. 67. 
being of a God, or makes observations concerning human affairs; when of a sudden I am surprized to find, that instead of the usual copulations of propositions, is, and is not, I meet with no proposition that is not connected with an ought or an ought not. This change is imperceptible; but is however, of the last consequence. For as this ought, or ought not, express some new relation or affirmation, this necessary that it should be observed and explained; and at the same time that a reason should be given for what seems altogether inconceivable, how this new relation can be a deduction from others which are entirely different from it. ${ }^{38}$

MacIntyre underlines here that although Hume expressed this claim in the form of doubt rather than in the form of positive assertion, his statement has reappeared later in the different texts of modern moral theories as a "truth of logic". And his idea has been canonized in the modern philosophy as following: moral conclusions cannot be derived from factual premises. ${ }^{39}$ For MacIntyre, what makes this statement important is the rejection of Aristotelian concept of functionality. ${ }^{40}$ MacIntyre analyses this rejection. Firstly, the supporters of this argument "took it for granted that no moral arguments involve functional concepts" in a conclusive way. ${ }^{41}$ The outcome of this argument can be seen best in the Hume's perception of virtues and rules. While Aristotle attributes to virtues -unlike the rules or laws- a role or function $^{42}$, Hume transforms the virtue of justice into nothing else than obeying its rules. ${ }^{43}$ For MacIntyre, this is a new relationship between virtues and rules. In other words, this relationship reduces the original content of the virtue of justice into a disposition to obey its precepts. And this view of Hume, as MacIntyre points out, has strong followers in modern and contemporary moral philosophy, for instance Kant, Mill and Rawls. ${ }^{44}$ And their common failure is very much related to the destroyed concept of Aristotelian functionality, ${ }^{45}$ which also unveils their "deep lack of historical consciousness" about the Aristotelian moral traditions. ${ }^{46}$

38 Hume, Treatise 469.

39 MacIntyre, After Virtue, p. 67. MacIntyre remarkably criticizes Hume's approach to this subjectmatter in his article "Hume on 'Is' and 'Ought' ", The Philosophical Review, vol: 68, No: 4 (Oct., 1959), pp. 451- 468.

40 Aristotle, NE 1097b and 1098a

41 MacIntyre, After Virtue, p. 69.

42 For example Aristotle, NE 1151a.

43 MacIntyre, After Virtue, p. 269f.

44 Rawls statement is quoted here by MacIntyre: "The virtues are sentiment, that is, related families of dispositions and propensities regulated by a higher-order desire, in this case a desire to act from the corresponding moral principles." See MacIntyre, After Virtue, p. 270f.

45 MacIntyre, After Virtue, p. $270 \mathrm{f}$.

46 MacIntyre, After Virtue, p. 70. 
Secondly, the transformation of the meaning of virtues into the meaning of rules has also radical effect on the moral language, because they do not belong to the same language anymore. ${ }^{47}$ As MacIntyre notices, there is a linguistic transition from the plural concept of "virtues" to the singular concept of "virtue". For example, from the end of the eighteenth century onwards, the words "moral" and "virtuous" have come to be used interchangeably. And in the same way, "duty" and "obligation"; "dutiful" and "virtuous" have been used as synonyms. However, in Aristotle, the phrase "moral virtue" does not contain a rhetorical tautology, because these two words have different meanings. It is crucial to notice that the result of these linguistic changes illustrate how moral vocabulary has become detached from its original context when it points to the one very specific and narrow moral understanding. That means the Aristotelian moral vocabulary has become simple and homogenous. ${ }^{48}$

In this part of the article, I aimed to understand the fundamental elements of Hume's moral philosophy and its outcomes within the modern emotivist morality, from MacIntyre's perspective in After Virtue. MacIntyre presents us these elements throughout After Virtue as anti-Aristotelian. Now the second task of the article will be to clarify MacIntyre's other perspective at Hume through his texts which are located at the outside of After Virtue.

47 I want to elaborate these three results of the absence of Aristotelian functionality in the modern emotivist statement that "moral conclusions cannot be derived from factual premises" through MacIntyre. Within Aristotelian morality, for instance, the human being is itself a functional concept, which means we can define the person in terms of her purpose or function. See here for example Aristotle, NE 1097b and 1098a. That is to say, she acts according to this particular purpose or function. Therefore in Aristotle's morality, we cannot separate the notion of a human being with the notion of being a good human. As a result of this, human nature has a teleological conception which develops itself according to its own function nesting in its own telos. Likewise, to call a particular action as good, just or right is always equal to say that this action is proper for a particular person in her particular situation. Thereby, every moral conclusion carries a functional statement within itself. Here it is important to realize that for MacIntyre, the doubt regarding the fact that the moral arguments can derive from the factual arguments is significantly connected with the displaced notion of human telos and human nature from the moral sphere in modern emotivist morality. MacIntyre notices here that as a result of this displacement in morality, it naturally becomes unintelligible to treat moral judgments as factual judgments. See MacIntyre, After Virtue, pp. 69-71.

48 MacIntyre, After Virtue, p. 271. And for MacIntyre, there are many other moral conceptions which need to be redefined after the Hume's distortion of the understanding of virtues, but we cannot exemplify each of them here because of the scope of the article. For the other examples see MacIntyre, After Virtue, p. 270. 


\section{The Second Perspective: MacIntyre's Understanding of Hume's morality as partly-Aristotelian in the texts outside of After Virtue}

MacIntyre's presentation of Hume as partly-Aristotelian is founded on Hume's idea of "communicated passion of sympathy" which brings a common social aspect to morality. ${ }^{49}$ Hume explains this sympathy in terms of the idea of shared human nature as he says "all human creatures are related to us by resemblance." 50 As MacIntyre indicates that, although Hume, because of his misconception of human nature gives an insufficient, incoherent and thus unjustified explanation for this idea, he realized the need of a social aspect in moral philosophy. Why is this important and how does it make Hume's morality as Aristotelian in this respect?

MacIntyre believes that every single theory or explanation in moral philosophy, either explicitly or implicitly, presupposes certain sociology. ${ }^{51}$ Nevertheless modern moral philosophy has failed to see this relationship. ${ }^{52}$ This failure creates a significant distinction between the understanding of morality in the past and the understanding of morality in the modern age. Morality in the past was always understood in the context of a social network and therefore, one of the main tasks of moral philosophy was the explanation and interpretation of a given socio-historical domain. However, MacIntyre identifies that morality alone in the modern age, at least since G. E. Moore, has taken a dominant role and consequently the relationship between morality and social structures has been ignored.53 Thus, the different practical rationalities in moral theories in different times and places are understood as historically frozen and timeless theories. ${ }^{54}$ The result of this approach to morality in the modern age is, as MacIntyre believes, a narrow and inaccurate understanding of morality. ${ }^{55}$

After this important explanatory framework in After Virtue, MacIntyre implies that Hume implicitly accepts the understanding of morality in the past. And in continuation of this, MacIntyre places Hume's moral philosophy together with Plato's and Aristotle's in the category of morality in the past. ${ }^{56}$ In addition to this classification, in a different place in the book, but still in the same context, he also indicates that "Hume's moral

49 For the social aspect of Aristotelian theory of justice see the Book V of NE.

50 Hume, Treatise 369.

51 MacIntyre, After Virtue, p. 27.

52 MacIntyre, The Tasks of Philosophy, p. 22.

53 MacIntyre, After Virtue, p. 27.

54 MacIntyre, "Practical Rationalities as Forms of Social Structure", Irish Philosophical Journal, vol: 4, Issue 1/2, 1987, pp. 3-19., p. 3.

55 MacIntyre, After Virtue, p. 27.

56 MacIntyre, After Virtue, p. 27. 
philosophy presupposes allegiance to a particular kind of social structure as much as Aristotle's does, but allegiance of a highly ideological kind". ${ }^{57}$ Strangely, MacIntyre undertakes no further explanations about his interpretations in After Virtue. In fact, these remarks are the starting point for his argument about the connection between Hume's and Aristotle's ethics as opposed to the modern understanding of morality, which he develops further in his other texts. The task of this section is now to unfold this connection.

That MacIntyre locates Hume within the understanding of morality in the past is based on Hume's philosophical transition from the egoistic perspective of first-person point of view in Book I to the social perspective of third person point of view in Book III of Morals in Treatise ${ }^{58}$ specifically where he discusses the virtue of justice and the origin of justice. According to the first-person point of view in philosophy, everything is comprehended and presented as the aspect of the personal impressions and ideas of ' $\mathrm{I}$ '. Therefore, philosophy and more particularly moral philosophy are considered as nothing else other than a personal narration and comprehension. But MacIntyre emphasizes Hume's shift from the firstperson point of view to "a third-person observer" in Book III. That means as MacIntyre understands, Hume changes his direction from the area of egoistic and narrow human understanding to a social and wider human understanding. For MacIntyre, Hume needs this change because of his doctrine of passion and its relationship with personal identity. ${ }^{59}$ Hume presupposes personal identity as a social concept providing the proper grounds for ascribing a governing function of passions to the identity. ${ }^{60}$

MacIntyre believes that identity is a social concept and it presupposes a responsibility and accountability of each person in her moral and practical life. Contrary to this, the first-person point of view denies any social content of personal identity, so that such identity "comes to seem a philosophically unwarranted fiction". ${ }^{61}$ This is the point where Hume rescues his account of passion from the character of first-person identity by including the idea of reciprocity of passion in a social context. In doing so, the self is identified as a member of a particular community where its identity is ascribed by the other members of society. ${ }^{62}$

57 MacIntyre, After Virtue, p. 269.

58 Hume, Treatise 477 and onwords.

59 MacIntyre, Whose Justice Which Rationality, Notre Dame: Notre Dame Press, 1988, p. 290.

60 MacIntyre, Whose Justice Which Rationality, p. 290f.

61 MacIntyre, Whose Justice Which Rationality, p. 291.

62 MacIntyre, Whose Justice Which Rationality, p. $292 \mathrm{f}$. 
As I have mentioned in the first part, Hume's understanding of the self socially was already recognized in Aristotle. Aristotle offers us a type of practical reasoning which necessarily requires a particular social setting. This requirement is a pre-condition for understanding human activity and the nature of human excellence. Hence, the framework of this comprehension is to exclude the understanding of practical reason in modern morality, where the dispositions of human nature and human actions are considered intelligible only in relationship with the satisfaction or frustration of personal desires and passions. The explanation of moral behavior hereafter will be grounded in the satisfaction of individual desires. ${ }^{63}$

As I have mentioned before, in modern practical reasoning, reason either is not present at all or has only an indirect role. This kind of practical reasoning is very problematic. At this point MacIntyre states: "Reasoning becomes practical then whenever it intervenes between a passion and the specification of how and in what way and in what form that passion's object is to be achieved." ${ }^{64}$ One example of the object of passion would be to have a passion for drinking milk in order to strengthen the bones or to have a passion for supporting a just system in order to ensure the stability of property. In both examples, we can easily notice that there is not just a passion here, but there is also a particular intentional object of the passion. ${ }^{65}$

In these examples, it is important to realize that the satisfaction of the passion is not attained by one single action, but by a sequence of other actions. That is to say, the passion does not give a reason for an action in its first premise. And MacIntyre positions here Hume's practical reasoning next to Aristotelian, as they are both contrary to the modern emotivist practical reasoning. He clearly formulates this commonality as follows "... in Humean reasoning just as much as in Aristotelian there is no place for a premise of the form only: 'I want such-and such'." 66 This statement is the fundamental point for MacIntyre in the comprehension of the similarity between Aristotle and Hume regarding their comprehensions of practical reasoning.

Now I should evaluate this similarity in their rejections of the statement 'I want such and such' through MacIntyre. We can begin with Aristotle. In

63 MacIntyre, "Practical Rationalities as Forms of Social Structure", p. 7f.

64 MacIntyre, "Practical Rationalities as Forms of Social Structure" p. 9.

65 MacIntyre, "Practical Rationalities as Forms of Social Structure", p. 9. See also MacIntyre, Whose Justice Which Rationality, p. 305.

66 MacIntyre, "Practical Rationalities as Forms of Social Structure", p. 9. See also again MacIntyre, Whose Justice Which Rationality, p. 305. 
Aristotelian practical reasoning, the statement such as 'I want' or 'it enjoys me' cannot be a reason for an action. ${ }^{67}$ In order to articulate a practical reasoning, one needs to have a moral education on how to feel pleasure and pain regarding different objects, states and experiences. Moral education means a transformation of desires into a new practical frame, so that the person would not have pleasure or pain as she had before. The person who is educated in how to feel desire for a particular action and judgment will be able to use her practical reasoning for moving herself with good reasons towards her telos. That's why, in the initial and primitive form, the statement 'I want such and such' will not move her to an action. ${ }^{68}$

Although in Humean practical reasoning there is also no such a statement as 'I want such and such', but the explanation of this statement is different from Aristotle. Contrary to Aristotle, for Hume, reason has not itself any practical role to move us to an action, unless it will be the servant of some passion. So, for Hume the statement 'I want such and such' cannot give us a reason to act. Why? MacIntyre interprets here Hume's two reasons. First, 'I want such and such' is an expressive, emotive utterance and thereby not a factual statement. The second reason is that the expression of passion, like the statement above, cannot move the person to act; only passion can itself accomplish it. ${ }^{69}$ According to MacIntyre, the vocabulary of Hume's idea of passion requires an intentionality, which contains a representation of its object, because passion is only directed to its object, and so it can motivate the person to act one way rather than another. However, the statement "I want such and such" has no intentionality, since it lacks any specific object. ${ }^{70}$

Either in Aristotelian or Humean societies the motivation for an action requires the negotiated reciprocity to maintain the satisfaction of passions. However, MacIntyre argues that the concept of passion from the standpoint of the modern understanding leads a frustration instead of satisfaction because of the absence of this reciprocity. ${ }^{71}$ And Hume labels such social order as "savage" order, because in the "savage" social order, we can

67 See for example; Aristotle, NE 1139a and 1139b.

68 MacIntyre, "Practical Rationalities as Forms of Social Structure", p. 9f.

69 MacIntyre, "Practical Rationalities as Forms of Social Structure", p. 9f. MacIntyre also differentiates Hume's account of action and passion from modern emotivist moral philosophy. Neither Stevenson nor Ayer has the vocabulary of a shared passion. Therefore, Hume's account of passion cannot be explained with the conception of self-interest. See MacIntyre, Whose Justice Which Rationality, p. 305 and 307.

70 MacIntyre, Whose Justice Which Rationality, p. 303.

71 MacIntyre, "Practical Rationalities as Forms of Social Structure", p. 16f. 
evaluate the social order only to the extent that the ends of the passions are accomplished. Hume says for example, in the Treatise:

And even every individual person must find himself a gainer on balancing the account; since, without justice, society must immediately dissolve, and everyone must fall into that savage and solitary condition, which is infinitely worse than the worst situation that can possibly be suppos'd in society. ${ }^{72}$

As we have already seen, the frame of understanding the passions can only be reasonable within the identified means of social organization and institutionalization of the artificial virtues. With this remark on Hume, MacIntyre invites us to read Hume's History of England as embodying the Humean moral system, which took place in the 16-18 ${ }^{\text {th }}$ centuries in England. There we can see the intertwined character of his philosophy with the social reality of his time. ${ }^{73}$

MacIntyre joins together these two different answers of Aristotle and Hume to the question of why there is not any practical reasoning in the statement 'I want such and such', by pointing to the common perception of socially shared passion between Aristotle and Hume. ${ }^{74}$ In another place, MacIntyre also understands, the modern emotivist statement 'I want' is replaced with the statement 'we want' in Aristotle and Hume, because here the statement 'I want' for Hume and Aristotle requires a transition from individual goods to common goods. And emotivist individualist moral philosophy cannot make this transition because there is no such a conception of common good defined by society. ${ }^{75}$ Therefore, MacIntyre concludes that both Aristotle and Hume have a notion of socially shared understanding of passions that implicitly or explicitly produce the actions, whether in Aristotelian or Humean terms. Whenever we respond to the actions of others, we will respond to the passions in the action. Therefore we always need a socially shared vocabulary of evaluation, approbation and disapprobation. ${ }^{76}$ Although Aristotle and Hume have important differences in terms of the understanding of action and human nature- as we have seen in the first part- they both understand the moral philosophy as socially constructed philosophy.

72 Hume, Treatise 497.

73 MacIntyre, "Practical Rationalities as Forms of Social Structure", p. $16 f$.

74 MacIntyre, "Practical Rationalities as Forms of Social Structure", p. 10.

75 MacIntyre, "Where We Were, Where We Are, Where We Need to Be", Virtue and Politics: Alasdair Macintyre's Revolutionary Aristotelianism, Notre Dame: University of Notre Dame Press, 2011, p. 314f.

76 MacIntyre,"Practical Rationalities as Forms of Social Structure”, p. 10. 
Although Hume shares the idea of social morality with Aristotle, MacIntyre points that their ideas about practical rationality were shaped by their very own social settings. That is to say, they can be reasonable only in their own social relationships. In Aristotle's case, it is the polis of the fifth and fourth centuries that supplies the Greeks the necessary settings for using a particular practical rationality, and in Hume's case, it is Britain of the eighteenth century that supplies the Englishmen the necessary settings for understanding the mutual character of passion in practical judgments. ${ }^{77}$

However, MacIntyre underlines that Hume would not accept his moral perception as understandable only within his historical locus, because he wants to have it as universal, like all modern emotivists claim. In contrast, Aristotle has no problem with such historical restriction in his moral understanding, because he already declares polis as the only practical domain for his moral philosophy. ${ }^{78}$ This difference is very significant, since it gives the answer of why MacIntyre designates Hume's allegiance of social structure as ideological in After Virtue, as I mentioned in the beginning of this part. Hume's mistake is to incorporate the particular social and cultural forms of his time into his conception of universal human nature. ${ }^{79}$ This is another point of difference between Aristotle and Hume regarding their common rejection of first-person point of view in emotivist practical reasoning.

Despite their differences the common characters of Aristotle's and Hume's practical reasoning bring them also together into the analogous defective perceiving of their moral philosophy by the mindset of modern moral philosophy. The first obstacle is the modern division among philosophy and natural and social sciences. The social structure of Aristotle's and Hume's moralities presuppose a relationship with human psychology, sociology, history and natural sciences. The understanding of moral philosophy in relation to these sciences is totally against the modern understanding of moral philosophy. As MacIntyre indicates, moral philosophy today is considered as an entirely theoretical and non-empirical form of inquiry. ${ }^{80}$

The understanding of moral philosophy as being independent from social studies makes modern morality a very formal study in philosophy.

77 MacIntyre, "Practical Rationalities as Forms of Social Structure”, p. 15.

78 MacIntyre, "Practical Rationalities as Forms of Social Structure", p. 11f.

79 MacIntyre, Whose Justice Which Rationality, p. 293.

80 MacIntyre, "Artifice, Desire, and Their Relationship: Hume against Aristotle", Persons and Passions, Essays in Honor of Annette Baier, University of Notre Dame Press: Notre Dame, 2005, pp. 192-210, p. 204- 207. 
This type of moral philosophy for MacIntyre, for instance, will never seek any relationship between morality and happiness, unless it is only accidental. As a result of this, the questioning in moral philosophy will remain always infertile. Therefore Hume's approach to moral issues will allow us to bridge the human condition and moral rules in a wider and more fruitful way than any other formalist modern moral approaches. ${ }^{81}$ According to MacIntyre, Hume sees cleverly intersection points of anthropology and psychoanalysis with philosophical ethics and understands it as a larger project. ${ }^{82}$ As in Aristotle's moral conception, Hume's moral understanding does not part itself from the concepts, such as wanting, needing, desiring, pleasure, happiness, health, etc., since Aristotle and Hume's moral philosophies will be unintelligible without these concepts. ${ }^{83}$

Aristotle and Hume understand the moral philosophy with one complex system of practical reasoning consisting one particular social, cultural and moral element. These will give them their own definition and recognition of human nature although they exclude each other's perceptions about human nature. Modern and contemporary philosophy in this case treats the philosophy as a micro-field philosophy, thus they examine the thesis or arguments in philosophy as piecemeal without its understanding in their large and systematic scales. ${ }^{84}$

Second obstacle to understand Aristotelian and Humean moral philosophy in the mindset of modern moral philosophy is about virtues. In Aristotle's understanding there is a relationship between virtues and social practice and in Hume's understanding there is a relationship between virtues and social moral commitments. So neither in Aristotle's ethics nor in Hume's ethics there is a neutral standpoint to evaluate morality. For that reason, Hume presents himself like Aristotle, teacher of morals and also moral philosopher. However, MacIntyre notices that the characterization of a moral philosopher as a moral is also very inadmissible attitude in modern academic philosophy. ${ }^{85}$

81 MacIntyre, "Hume on 'Is' and 'Ought' ", p. 462.

82 MacIntyre, "Introduction", Hume's Ethical Writings, Notre Dame: University of Notre Dame Press, 1965, p. 16.

83 MacIntre, "Hume on 'Is' and 'Ought' ", p. 463, 466. MacIntyre here contrasts Hume's morality with Kantian morality and claims that Hume has never attempt to establish an autonomous morality which has a lack of basis. That the concept of good and right, in Hume's morality, require a relationship with human needs and desires, makes Hume's moral philosophy a strongly different from Kant.

84 MacIntyre, "Artifice, Desire, and Their Relationship: Hume against Aristotle", p. 208f.

85 MacIntyre, "Artifice, Desire, and Their Relationship: Hume against Aristotle", p. 205f. 


\section{Conclusion}

It can be obviously said, MacIntyre's understanding of Hume has two perspectives which cannot be separated from each other and they need to be followed in MacIntyre's different texts simultaneously. In the first perspective of MacIntyre, I have tried to show how he, in After Virtue, describes Hume especially through Treatise, as anti-Aristotelian in the emotivist context. In the emotivist elements of Hume's moral philosophy, moral judgements are understood as nothing more than our preferences, and passions. In this moral framework, the problem of incommensurability of moral judgements arises, since they have an unstable ground to have a sound moral standpoint in a society, especially when it comes to acting in line with justice. For MacIntyre, the modern emotivism cannot solve the problem of incommensurability unless it changes its moral ground to an Aristotelian one.

In the second perspective of MacIntyre, I have argued for that MacIntyre's presentation of Hume in After Virtue need to be supplemented with his other texts, since in these texts MacIntyre presents Hume's practical rationality as the one resembling Aristotle's in the Enquiry. MacIntyre sheds the light on Hume's concept of the passion regardless his defective explanation about the relationship beween human nature and passion. Aside from this defection, Hume recognizes in the Treatise the problem of the incommensurability of being moral and assumedly tries to surmount it with his concept of the "communicated passion of sympathy" which shows togetherness of moral judgements and society, as it is illustraded by Aristotle.

This togetherness of Aristotle and Hume in terms of social aspect of morality resonates also in their perspectives about how to act in terms of their understandings on the practical rationalities. Their ways of dealing with practical rationality show important similarities. Therefore for MacIntyre, they certainly have a significant advantage against the modern and contemporary individualist philosophies because they simply cannot even enter into rivalry with the systematic characters of Aristotle and Hume's practical rationalities. ${ }^{86}$

This is the holistic reading of MacIntyre's Hume as anti- and proAristotelian. It is also necessary to say that these two perspectives of MacIntyre at Hume reveal no contradiction because they handle two different issues in Hume's moral philosophy. And that MacIntyre did not go over these distinctions and seems to ignore them in After Virtue does not

86 MacIntyre, “Artifice, Desire, and Their Relationship: Hume against Aristotle”, p. 209. 
mean that MacIntyre changed his idea about Hume in his later writings. Rather, it means that he focuses in After Virtue not just Hume but also modern morality generally, so he seems to have the opportunity to make more lucid clarifications on Hume in his later texts. In addition to this we also have seen that MacIntyre in his later texts repeats the same critiques on Hume which he has already made in After Virtue.

\section{Bibliography}

Alasdair MacIntyre, After Virtue: A Study in Moral Theory, New York: Bloomsbury, 3rd. Edition, 2011.

The Tasks of Philosophy, vol: 1, Cambridge: Cambridge University Press, 2006.

Whose Justice Which Rationality, Notre Dame: Notre Dame Press, 1988. "Moral Philosophy: What Next?", Revisions: Changing Perspectives in Moral Philosophy, Notre Dame: University of Notre Dame Press, 1983, pp. 1-15.

"Hume on 'Is' and 'Ought' ", The Philosophical Review, vol: 68, No: 4 (Oct., 1959), pp. 451- 468.

"Practical Rationalities as Forms of Social Structure", Irish Philosophical Journal, vol: 4, Issue 1/2, 1987, pp. 3-19.

"Where We Were, Where We Are, Where We Need to Be", Virtue and Politics: Alasdair Macintyre's Revolutionary Aristotelianism, Notre Dame: University of Notre Dame Press, 2011, pp. 307-334.

"Artifice, Desire, and Their Relationship: Hume against Aristotle", Persons and Passions, Essays in Honor of Annette Baier, University of Notre Dame Press: Notre Dame, 2005, pp. 192-210.

"Introduction", Hume's Ethical Writings: Selections from David Hume, Notre Dame: University of Notre Dame Press, 1965, pp. 9-17.

(Ed.), Hume's Ethical Writings: Selections from David Hume, Notre Dame: University of Notre Dame Press, 1965.

Aristotle, Nicomachean Ethics, tr. and ed. by Roger Crisp, Cambridge: Cambridge University Press, 2000.

David Hume, A Treatise of Human Nature, David Fate and Mary J. Norton (Ed.), Oxford: Oxford University Press, 2000. 